\title{
ANALISIS ECONOMIC VALUE ADDED (EVA), FINANCIAL VALUE ADDED (FVA) DAN MARKET VALUE ADDED (MVA) DENGAN TIME SERIES APPROACH SEBAGAI ALAT PENILAIAN KINERJA KEUANGAN (Studi Pada Industri Konstruksi (BUMN) di Indonesia Yang Listing di BEI Tahun 2013-2017)
}

\author{
Nardi Sunardi ${ }^{1)}$ \\ 1) dosen universitas pamulang, email : dosen01030@unpam.ac.id
}

\section{ARTICLES \\ INFORMATION}

\section{JURNAL SEKURITAS \\ (Saham, Ekonomi, Keuangan dan Investasi )}

Vol.2, No.1, September 2018 Halaman : 62-76

(c) LPPM \& Prodi Manajemen UNIVERSITAS PAMULANG

ISSN (online) : 2581-2777 ISSN (print) : : 2581-2696

Keyword:

Economic Value Added (EVA), Financial Value Added (FVA) dan Market Value Added (MVA) Kinerja Perusahaan Konstruksi

JEL. classification :

C31, E50

\section{Contact Author :}

PRODI MANAJEMEN UNPAM JL.Surya Kencana No.1 Pamulang

Tangerang Selatan - Banten Telp. (021) 7412566, Fax (021) 7412491 Email :

jurnalfinance.unpam@gmail.com
Penelitian ini bertujuan untuk mengetahu kinerja keuangan perusahaan Industri Konstruksi (BUMN) di Indonesia yang listing di Bursa Efek Indonesia Periode 2013-2017 dengan pendekatan Economic Value Added (EVA), Financial Value Added (FVA) dan Market Value Added (MVA) dengan Time Series Approach, Hasil penelitian ini menunjukkan bahwa Perusahaan PT.Adhi Karya (Persero)Tbk, PT.Wijaya Karya (Persero) dan PT. Waskita Karya (Persero) dengan nilai EVA adalah negatif ini berarti berkinerja tidak baik. sedangkan PT. PP (Persero) Tbk adalan positif berarti berkinerja baik, PT.Adhi Karya (Persero)Tbk, nilai rata-rata FVA adalah negatif berarti berkinerja tidak baik.. Sedangkan nilai ratarata EVA pada PT. PP (Persero) Tbk, PT.Wijaya Karya (Persero), dan PT. Waskita Karya (Persero) adalan positif berarti berkinerja baik, PT.Adhi Karya (Persero)Tbk, PT. PP (Persero) Tbk, PT.Wijaya Karya (Persero), dan PT. Waskita Karya (Persero) nilai rata-rata MVA adalah negatif berarti berkinerja tidak baik,Kinerja keuangan perusahaan Konstruksi (BUMN) di Indonesia secara simutan sebesar 2,091 nunjukan hasill positif berarti berkinerja baik.

This study aims to find out the financial performance of Construction Industry Company (BUMN) in Indonesia listing on Indonesia Stock Exchange Period 2013-2017 with Economic Value Added (EVA), Financial Value Added (FVA) dan Market Value Added (MVA) by Time Series Approach (TSA), The result of this research indicate that Company PT. Adhi Karya (Persero) Tbk, PT.Wijaya Karya (Persero) and PT. Waskita Karya (Persero) with EVA value is negative this means it is performing not good. while PT. PP (Persero) Tbk is a positive means that it performs good, PT. Adhi Karya (Persero) Tbk, the average value of FVA is negative means that it performs not good. While the average value of EVA at PT. PP (Persero) Tbk, PT.Wijaya Karya (Persero), and PT. Waskita Karya (Persero) is positive means that it performs good, PT. Adhi Karya (Persero) Tbk, PT. PP (Persero) Tbk, PT.Wijaya Karya (Persero), and PT. Waskita Karya (Persero) the average value of MVA is negative, meaning that it performs not good, the financial performance of a construction company (BUMN) in Indonesia by 2,091 shows a positive result means that it is performing good. 


\section{A. Pendahuluan}

Perkembangan dunia dalam perekonomian modern laporan keuangan sudah merupakan media penting dalam proses pengambilan keputusan ekonomi. Laporan keuangan perusahaan lazim diterbitkan secara periodik bisa tahunan, semesteran, triwulan, bulanan, bahkan bisa harian. Laporan keuangan ini sudah menjadi kebutuhan utama pihak-pihak dalam proses pengambilan keputusannya. Penilaian kinerja keuangan perusahaan sangat penting bagi perusahaan untuk mengetahui pengalokasian aktiva yang dimiliki secara efektif dan efisien guna mencapai tujuan perusahaan yaitu memperoleh laba maksimal untuk mempertahankan eksistensi perusahaan. Perusahan yang ingin tetap mempertahankan eksistensinya perlu untuk mengadakan evaluasi atau penilaian terhadap kinerja perusahaan, khususnya kinerja keuangan yang menjadi salah satu faktor penunjang perusahaan dalam menjalankan proses bisnis yang semakin kompetitif. Pengukuran kinerja keuangan merupakan salah satu strategi untuk mengelola keuangan agar perusahaan tetap mampu bertahan dan bersaing.

Pendekatan dengan analisis keuangan pendekatan Economic Value Added (EVA), Financial Value Added (FVA) dan Market Value Added (MVA) dengan Time Series Approach merupakan salah satu alat ukur kinerja keuangan yang relevan digunakan untuk melihat sejauh mana efektivitas perusahaan dalam pengembalian atas investasi dilakukan oleh perusahaan dengan menggunakan ukuran kinerja yang dilihat dari nilai tambah (Value Based) yaitu konsep Economic Value Added (EVA), Financial Value Added (FVA) dan Market Value Added (MVA).

Objek penelitian dilakukan pada perusahaan go public yang bergerak dibidang Pada Industri Konstruksi (BUMN) di Indonesia yang Listing di Bursa Efek Indonesia Tahun 2013-2017 yaitu PT.Adhi Karya (Persero) Tbk., PT. PP (Persero) Tbk., PT.Wijaya Karya (Persero) Tbk, dan PT. Waskita Karya (Persero) Tbk Berikut.

EVA atau nilai tambah ekonomi adalah perbedaan laba usaha setelah pajak (NOPAT) dan beban modal untuk periode tersebut (yaitu, produk dari biaya modal perusahaan dan modal yang diinvestasikan pada awal periode). Sedangkan FVA untuk mengukur kinerja perusahaan yang mempertimbangkan kontribusi dari fixed assets dalam menghasilkan keuntungan bersih perusahaan dan MVA merupakan alat untuk mengukur berapa banyak kekayaan suatu perusahaan yang telah diciptakan untuk saat tertentu. Metode penelitian yang digunakan adalah metode deskriptif kuantitatif dengan sampel perusahaan Industri Konstruksi (BUMN) di Indonesia yang Listing di Bursa Efek Indonesia Tahun 2013-2017.

"Pengertian Economic Value Added (EVA) adalah tolak ukur kinerja keuangan dengan mengukur perbedaan antara pengembalian atas modal perusahaan dengan biaya modal" (Young dan Stephen). Sedangkan "Market Value Added (MVA) adalah perbedaan antara nilai pasar ekuitas perusahaan pada periode tertentu dengan nilai ekuitas yang dipasok para investornya. MVA hanya dapat dihitung atau diaplikasikan pada perusahaan publik atau yang listed di pasar modal" (Warsono) Selain menggunakan EVA dan MVA, dapat digunakan FVA untuk untuk mengukur kinerja perusahaan (Iramani \& Febrian). Metode ini mempertimbangkan kontribusi dari fixed assets dalam menghasilkan keuntungan bersih perusahaan. Berdasarkan uraian maka penulis mencoba meneliti kinerja keuangan dengan menggunakan 3 metode yaitu EVA, FVA dan MVA.

Dari latar belakang tersebut, maka penulis mengambil judul "Analisis Economic Value Added (EVA), Financial Value Added (FVA) dan Market Value Added (MVA) dengan Time Series Approach Sebagai Alat Penilaian Kinerja Keuangan (Studi Pada Industri Konstruksi (BUMN) di Indonesia Yang Listing di BEI Tahun 20132017)". 


\section{B. Perumusan Masalah}

Berdasarkan latar belakang masalah di atas maka masalah yang akan dibahas dan dicari jawabannya dalam penelitian ini adalah :

1. Bagaimana Penilaian Kinerja Keuangan Perusahaan yang listing di Bursa Efek Indonesia Tahun 2013-2017 berdasarkan metode Economic Value Added?

2. Bagaimana Penilaian Kinerja Keuangan Perusahaan yang listing di Bursa Efek Indonesia Tahun 2013-2017 berdasarkan metode Financial Value Added?

3. Bagaimana Penilaian Kinerja Keuangan Perusahaan yang listing di Bursa Efek Indonesia Tahun 2013-2017 berdasarkan metode Market Value Added?

\section{Landasan Teori}

\section{Kinerja Keuangan}

Menurut Keputusan Menteri Keuangan Republik Indonesia No. 740/ KMK.00/1989 tentang Peningkatan Efisiensi dan Produktivitas Badan Usaha Milik Negara "Kinerja keuangan adalah prestasi yang dicapai oleh perusahaan dalam periode tertentu yang mencerminkan tingkat kesehatan perusahaan tersebut. Kinerja keuangan perusahaan merupakan salah satu dasar penilaian mengenai kondisi-kondisi keuangan yang dapat dilakukan berdasarkan analisis rasio- rasio keuangan."

Kinerja dapat diartikan sebagai prestasi yang dicapai perusahaan dalam suatu periode tertentu yang mencerminkan tingkat kesehatan perusahaan tersebut" (Winarni dan Sugiyarso, 2005:111). Kinerja keuangan merupakan suatu analisis dalam periode waktu tertentu untuk mengukur suatu gambaran kondisi perusahaan dengan menggunakanaturan pelaksanaan keuangan secara baik dan benar. Menurut Sucipto (2003) mengatakan kinerja keuangan adalah penentuan suatu ukuran tertentu yang dapatmengukur keberhasilan suatu organisasi atau perusahaan dalam menghasilkan laba.Kinerja keuangan dapat diukur dengan cara menganalisis dan mengevaluasi laporan keuangan perusahaan.

\section{Economic Value Added (EVA)}

Economic Value Added senbagai tolak ukur kinerja keuangan dengan mengukur perbedaan antara pengembalian atas modal perusahaan dengan biaya modal (Young dan O'Byrne). Menurut Keown, dkk. rumus EVA adalah

EVA = NOPAT - (WACC x IC)

\begin{tabular}{|l|l|}
\hline \multicolumn{1}{|c|}{ Komponen EVA } & \multicolumn{1}{c|}{ Rumus } \\
\hline NOPAT & Pendapatan Usaha Bersih $(1-$ Tarif Pajak $)$ \\
\hline WACC & {$[($ D xd $)(1$-tax $)+($ E $\times$ re $)]$} \\
\hline IC & (Total Hutang + Ekuitas $)-$ Hutang Jangka Pendek \\
\hline EVA & NOPAT $-($ WACC $\times$ IC $)$ \\
\hline
\end{tabular}

\section{Keterangan:}

NOPAT : Net Operating Profit After Tax (Laba operasi bersih setelah pajak)

WACC : Weighted Average Cost of Capital (Biaya modal rata - rata tertimbang)

D : : Biaya modal hutang

rd : Persentase hutang dalam struktur modal Tax : Pajak

E : Biaya modal ekuitas

re : Persentase biaya modal pada struktur modal

IC : Invested Capital

EVA : Economic Value Added 
EVA > 0 maka menunjukkan telah terjadi proses nilai tambah pada perusahaan dan berhasil menciptakan nilai bagi penyedia dana. Tingkat pengembalian yang dihasilkan lebih besar daripada tingkat biaya modal atau tingkat biaya yang diharapkan investor atas investasi yang dilakukannya. EVA $=0$ menunjukkan posisi impas perusahaan karena semua laba digunakan untuk membayar kewajiban kepada penyedia dana baik kreditor maupun pemegang saham. EVA $<0$ menunjukkan tidak terjadinya proses nilai tambah karena laba yang tersedia tidak dapat memenuhi harapan para investor. Nilai perusahaan berkurang akibat tingkat pengembalian yang dihasilkan lebih rendah dari tingkat pengembalian yang diharapkan penyedia dana (investor).

\section{Financial Value Added (FVA)}

Financial Value Added merupakan metode dalam mengukur kinerja dan nilai tambah perusahaan. Metode ini mempertimbangkan kontribusi dari fixed assets dalam menghasilkan keuntungan bersih perusahaan (Iramani dan Febrian). Menurut Rodrigues perhitungan Financial Value Added (FVA) dapat diperoleh dengan menggunakan rumus sistemastis sebagai berikut;

$$
\text { FVA }=\text { NOPAT }-(E D-D)
$$

Langkah Perhitungan FVA

\begin{tabular}{|l|l|}
\hline \multicolumn{1}{|c|}{ Komponen FVA } & \multicolumn{1}{c|}{ Rumus } \\
\hline NOPAT & Pendapatan Usaha Bersih (1 - Tarif Pajak) \\
\hline ED & k x TR \\
\hline FVA & NOPAT - (ED-D) \\
\hline
\end{tabular}

Keterangan:

NOPAT : Net Operating Profit After Tax (Laba operasi bersih setelah pajak)

ED : Biaya modal hutang

FVA : Financial Value Added

Menghitung Equivalent Depreciations

$\mathrm{ED}=\mathrm{k} \times \mathrm{TR}$

Dimana : ED = Equivalent Depreciations

$\mathrm{k}=$ Biaya Modal rata-rata tertimbang (WACC)

$T R($ Total Resource $)=$ Hutang Jangka Panjang + Total Equity

\section{Mencari k adalah}

Menghitung WACC (Weighted Average Cost Of Capital)

Rumus : WACC $=[(\mathrm{D} \times \mathrm{rd})(1-\operatorname{tax})+(\mathrm{E} \times \mathrm{re})]$

Dimana :

$$
\text { Tingkat Modal }(D)=\frac{\text { Total Hutang }}{\text { Total Hutang dan Ekuitas }} \times 100 \%
$$

Nilai FVA $>0$ atau FVA bernilai positif menunjukkan terjadi nilai tambah financial bagi perusahaan. Nilai FVA $=0$ menunjukkan posisi impas. Nilai FVA $<0$ atau FVA bernilai negative menunjukkan tidak terjadi nilai tambah financial bagi perusahaan. 


\section{Market Value Added (MVA)}

Menurut Keown dkk. Market Value Added (MVA) dapat diartikan sebagai perbedaan nilai pasar antara perusahaan dan modal yang telah diinvestasikan. MVA dapat dihitung sebagai berikut:

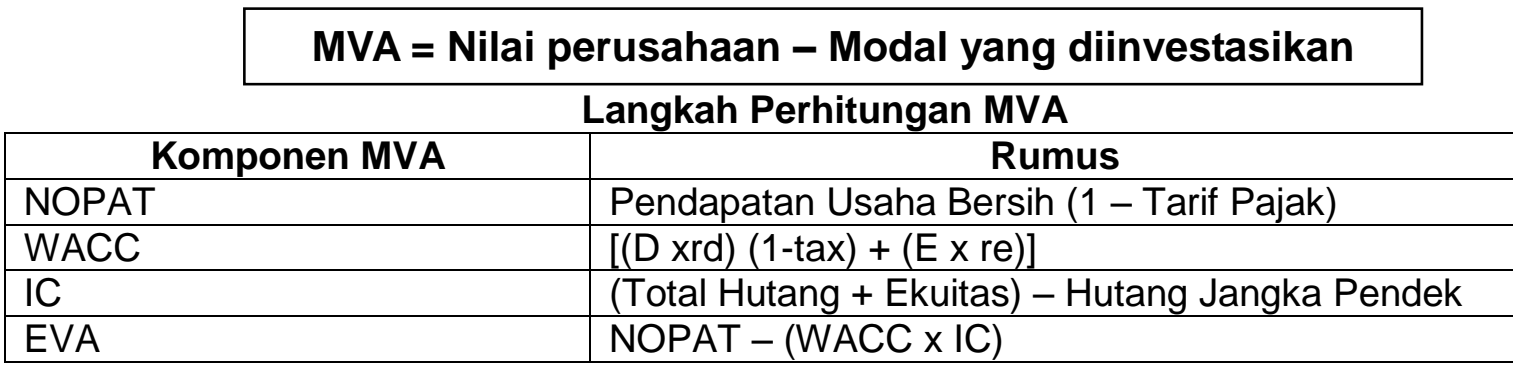

Keterangan:

NOPAT : Net Operating Profit After Tax (Laba operasi bersih setelah pajak)

WACC : Weighted Average Cost of Capital (Biaya modal rata - rata tertimbang)

D : Biaya modal hutang

rd : Persentase hutang dalam struktur modal Tax : Pajak

E : Biaya modal ekuitas

re : Persentase biaya modal pada struktur modal

IC : Invested Capital

EVA : Economic Value Added

MVA positif, berarti pihak manajemen perusahaan telah mampu meningkatkan kekayaan perusahaan dan para pemegang saham atau bisa dikatakan kinerja perusahaan tersebut baik. MVA negatif, berarti pihak manajemen tidak mampu atau telah menurunkan kekayaan perusahaan dan kekayaan para pemegang saham, atau bisa dikatakan bahwa kinerja perusahaan tidak baik.

\section{Metoda Penelitian}

Jenis Penelitian ini merupakan penelitian deskriptif dengan pendekatan kuantitatif. maka dapat disusun kerangka pikir yang menggambarkan tentang analisis penilaian kinerja keuangan perusahaan dengan menggunakan metode Economic Value Added (EVA), Financial Value Added (FVA) dan Market Value Added (MVA) kemudian membuat kesimpulan dengan menggunakan metode Cross sectional approach dan Time Series Analysis, sehingga dari kesimpulan ini dapat diketahui kinerja keuangan keuangan.

Populasi dan sampel dalam penelitian ini di Bursa Efek Indonesia periode 20132017 Populasi dalam penelitian ini adalah Perusahaan pada Industri Konstruksi (BUMN) di Indonesia Yang Listing Di Bursa Efek Indonesia periode 2013-2017 dan situs internet www.idx.co.id.

Sampel Penelitian sbb:

\begin{tabular}{ccl}
\hline No. & Kode & \multicolumn{1}{c}{ Perusahaan Konstruksi (BUMN) di Indonesia } \\
\hline 1 & ADHI & PT.Adhi Karya (Persero) Tbk \\
2 & PTPP & PT. PP (Persero) Tbk \\
3 & WIKA & PT.Wijaya Karya (Persero) Tbk \\
4 & WSKT & PT. Waskita Karya (Persero) Tbk \\
\hline
\end{tabular}

Teknik analisis data metode analisis data yang diperlukan secara kuantitatif denga berdasarkan data skunder yang telah dikumpulkan. Analisis data dilakukan dengan 
mengelolah data-data yang diperoleh kemuadian menganalisisnya. Tahapan-tahapan analisis data:

1. Mendapatkan data yang diperlukan dari laporan keuangan tahunan untuk periode 2013 sampai 2017

2. Menghitung komponen EVA

a. Menghitung NOPAT berdasarkan laporan keuangan perusahaan.

NOPAT $=$ Pendapatan Usaha Bersih (1 - Tarif Pajak)

b. Menghitung Invested Capital

Invested Capital $=($ Total Hutang + Ekuitas $)-$ Hutang Jangka Pendek

c. Menghitung WACC (Weighted Average Cost of Capital) WACC $=[(\mathrm{D} \times \mathrm{rd})(1-$ tax $)+(E \times$ re $)]$

Tingkat Modal $(D)=\frac{\text { Total Hutang }}{\text { Total Hutang dan Ekuitas }} \times 100 \%$

Cost of Debt $(r d)=$ Beban Bunga $\times 100 \%$

Tingkat Modal/Ekuitas $(E)=\frac{\text { Total Ekuitas }}{\text { Total Hutang dan Ekuitas }} \times 100 \%$

Cost of Equity $=$ Laba bersih setelah pajak $\times 100 \%$

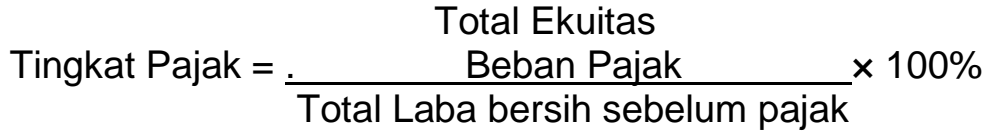

d. Menghitung Capital Charges

Capital Charges = WACC x Invested Capital

e. Menghitung EVA

EVA = NOPAT - Capital Charges

f. Dianalisis berdasarkan tolak ukur EVA

3. Menghitung komponen FVA

a. Menghitung NOPAT berdasarkan laporan keuangan perusahaan

b. Menghitung Equivalent Depreciation

$\mathrm{ED}=\mathrm{k} \times \mathrm{TR}$

c. Menghitung Depreciation

1) Metode Garis Lurus Penyusutan Tahunan = Biaya-estimasi nilai residu

Estimasi masa kegunaan

2) Metode Unit Produksi Penyusutan per jam = Biaya-estimasi nilai residu Estimasi (jam)

3) Metode Saldo Menurun Ganda Tingkat Saldo Menurun Ganda = Metode Garis Lurus $\times 2$

d. Menghitung FVA

$F V A=$ NOPAT $-(E D-D)$

e. Dianalisis berdasarkan tolak ukur FVA

4. Menghitung komponen MVA

a. Menghitung jumlah saham yang beredar (the number of share outstanding)

b. Menghitung harga per saham (share price)

c. Menghitung nilai buku ekonomis per lembar saham (economic book value per share)

d. Menghitung MVA

MVA = Nilai perusahaan - Modal yang diinvestasikan

e. Menganalisis berdasarkan tolak ukur MVA

5. Menarik kesimpulan berdasarkan hasil perhitungan tersebut. 


\section{Hasil dan Pembahasan}

1. Analisis dan Interpretasi Kinerja Keuangan Metode Economic Value Added (EVA), Financial Value Added (FVA) dan Market Value Added (MVA) PT.Adhi Karya (Persero) Tbk.

Kinerja Keuangan Perusahaan PT.Adhi Karya (Persero) Tbk. sebagai berikut :

Tabel 1 : Rekapitulasi Kinerja Keuangan Perusahaan PT.Adhi Karya (Persero) Tbk Periode 2013-2017 (Dalam Milyaran Rupiah)

\begin{tabular}{|c|r|r|r|r|r|c|c|}
\hline \multirow{2}{*}{ Variabel } & \multicolumn{5}{|c|}{ Periode } & $\begin{array}{c}\text { Rata- } \\
\text { rata }\end{array}$ & Kinerja \\
\cline { 2 - 8 } & $\mathbf{2 0 1 3}$ & $\mathbf{2 0 1 4}$ & $\mathbf{2 0 1 5}$ & $\mathbf{2 0 1 6}$ & $\mathbf{2 0 1 7}$ & -149 & Baik \\
\hline Economic Value Added (EVA) & -16 & -96 & -312 & -219 & -100 & -149 & $\begin{array}{c}\text { Tidak } \\
\text { Baik }\end{array}$ \\
\hline Financial Value Added (FVA) & -671 & -755 & $-1,078$ & $-1,082$ & -839 & -885 & \\
\hline Market Value Added (MVA) & $-3,179$ & $-3,418$ & $-7,347$ & $-7,051$ & $-10,700$ & $-6,339$ & Baik \\
\hline
\end{tabular}

Berdasarkan tabel 1 rekapitulasi kinerja Keuangan Perusahaan PT.Adhi Karya (Persero) Tbk Periode 2013-2017 diatas terlihat Economic Value Added (EVA) menunjukkan kondisi perusahaan berkinerja baik dikarenakan nilai rata-rata EVA sebesar -149 diatas rata-rata industri -336 artinya kinerja perusahaan dilihat dari EVA berkinerja baik, Financial Value Added (FVA) menunjukkan kondisi perusahaan berkinerja tidak baik dikarenakan nilai rata-rata FVA sebesar -885 diibawah rata-rata industri $-14,256$ artinya kinerja perusahaan dilihat dari FVA berkinerja Tidak baik, Market Value Added (MVA) menunjukkan kondisi perusahaan berkinerja baik dikarenakan nilai rata-rata MVA sebesar -6,339 diatas rata-rata industri $-14,256$ artinya kinerja perusahaan dilihat dari MVA berkinerja baik.

2. Analisis dan Interpretasi Kinerja Keuangan Metode Economic Value Added (EVA), Financial Value Added (FVA) dan Market Value Added (MVA) PT. PP (Persero) Tbk.

Kinerja Keuangan Perusahaan PT. PP (Persero) Tbk. sebagai berikut :

Tabel 2 : Rekapitulasi Kinerja Keuangan Perusahaan PT. PP (Persero) Tbk. Periode 2013-2017 (Dalam Milyaran Rupiah)

\begin{tabular}{|l|r|r|r|r|r|r|r|}
\hline \multirow{2}{*}{ Variabel } & \multicolumn{5}{|c|}{ Periode } & Rata- & \multirow{2}{*}{$\begin{array}{c}\text { Kinerja } \\
\text { rata }\end{array}$} \\
\cline { 2 - 8 } & $\mathbf{2 0 1 3}$ & $\mathbf{2 0 1 4}$ & $\mathbf{2 0 1 5}$ & $\mathbf{2 0 1 6}$ & $\mathbf{2 0 1 7}$ & \\
\hline Economic Value Added (EVA) & 24 & 54 & -33 & 298 & 196 & 108 & Baik \\
\hline Financial Value Added (FVA) & 11,227 & 13,386 & 17,493 & 29,750 & 33,891 & 21,149 & Baik \\
\hline Market Value Added (MVA) & $-3,602$ & $-4,773$ & $-8,388$ & $-15,354$ & $-18,502$ & $-10,124$ & Baik \\
\hline
\end{tabular}

Berdasarkan tabel 2 rekapitulasi kinerja Keuangan Perusahaan PT. PP (Persero) Tbk. Periode 2013-2017 diatas terlihat Economic Value Added (EVA) menunjukkan kondisi perusahaan berkinerja baik dikarenakan nilai rata-rata EVA sebesar 108 diatas rata-rata industri -336 artinya kinerja perusahaan dilihat dari EVA berkinerja baik, Financial Value Added (FVA) menunjukkan kondisi perusahaan berkinerja baik dikarenakan nilai rata-rata FVA sebesar 21,149 diatas rata-rata industri -14,256 artinya kinerja perusahaan dilihat dari FVA berkinerja baik, Market Value Added (MVA) menunjukkan kondisi perusahaan berkinerja baik dikarenakan nilai rata-rata MVA sebesar -10,124 diatas rata-rata industri -14,256 artinya kinerja perusahaan dilihat dari MVA berkinerja baik. 
3. Analisis dan Interpretasi Kinerja Keuangan Metode Economic Value Added (EVA), Financial Value Added (FVA) dan Market Value Added (MVA) PT.Wijaya Karya (Persero) Tbk

Kinerja Keuangan Perusahaan PT.Wijaya Karya (Persero) Tbk. sebagai berikut :

Tabel 3 : Rekapitulasi Kinerja Keuangan Perusahaan PT.Wijaya Karya (Persero)

Tbk. Periode 2013-2017 (Dalam Milyaran Rupiah)

\begin{tabular}{|c|c|c|c|c|c|c|c|}
\hline \multirow{2}{*}{ Variabel } & \multicolumn{5}{|c|}{ Periode } & \multirow{2}{*}{$\begin{array}{l}\text { Rata- } \\
\text { rata }\end{array}$} & \multirow{2}{*}{ Kinerja } \\
\hline & 2013 & 2014 & 2015 & 2016 & 2017 & & \\
\hline Economic Value Added (EVA) & 287 & 136 & -124 & -496 & -888 & -217 & Baik \\
\hline Financial Value Added (FVA) & 11,924 & 14,817 & 18,130 & 28,486 & 41,060 & 22,883 & Baik \\
\hline Market Value Added (MVA) & $-2,890$ & $-7,179$ & $-8,988$ & $-16,435$ & $-19,688$ & $-11,036$ & Baik \\
\hline
\end{tabular}

Berdasarkan tabel 3 rekapitulasi kinerja Keuangan Perusahaan PT.Wijaya Karya (Persero) Tbk. Periode 2013-2017 diatas terlihat Economic Value Added (EVA) menunjukkan kondisi perusahaan berkinerja baik dikarenakan nilai rata-rata EVA sebesar -217 diatas rata-rata industri -336 artinya kinerja perusahaan dilihat dari EVA berkinerja baik, Financial Value Added (FVA) menunjukkan kondisi perusahaan berkinerja baik dikarenakan nilai rata-rata FVA sebesar 22,883 diatas rata-rata industri -14,256 artinya kinerja perusahaan dilihat dari FVA berkinerja baik, Market Value Added (MVA) menunjukkan kondisi perusahaan berkinerja baik dikarenakan nilai rata-rata MVA sebesar $-11,036$ diatas rata-rata industri $-14,256$ artinya kinerja perusahaan dilihat dari MVA berkinerja baik.

4. Analisis dan Interpretasi Kinerja Keuangan Metode Economic Value Added (EVA), Financial Value Added (FVA) dan Market Value Added (MVA) PT. Waskita Karya (Persero) Tbk.

Kinerja Keuangan Perusahaan PT. Waskita Karya (Persero) Tbk. sebagai berikut : Tabel 4 : Rekapitulasi Kinerja Keuangan Perusahaan PT. Waskita Karya (Persero) Tbk. Periode 2013-2017 (Dalam Milyaran Rupiah)

\begin{tabular}{|c|c|c|c|c|c|c|c|}
\hline \multirow{2}{*}{ Variabel } & \multicolumn{5}{|c|}{ Periode } & \multirow{2}{*}{$\begin{array}{l}\text { Rata- } \\
\text { rata }\end{array}$} & \multirow{2}{*}{ Kinerja } \\
\hline & 2013 & 2014 & 2015 & 2016 & 2017 & & \\
\hline Economic Value Added (EVA) & 89 & 91 & 65 & -431 & $-5,248$ & $-1,087$ & \begin{tabular}{|c|} 
Tidak \\
Baik
\end{tabular} \\
\hline Financial Value Added (FVA) & 8,141 & 11,625 & 28,929 & 57,856 & 95,042 & 40,318 & Baik \\
\hline Market Value Added (MVA) & $-3,361$ & $-4,814$ & 16,644 & $-30,149$ & $-92,665$ & $-29,527$ & $\begin{array}{l}\text { Tidak } \\
\text { Baik }\end{array}$ \\
\hline
\end{tabular}

Sumber: Data Diolah, 2018

Berdasarkan tabel 4 rekapitulasi kinerja Keuangan Perusahaan PT. Waskita Karya (Persero) Tbk. Periode 2013-2017 diatas terlihat Economic Value Added (EVA) menunjukkan kondisi perusahaan berkinerja tidak baik dikarenakan nilai ratarata EVA sebesar -1,087 dibawah rata-rata industri -336 artinya kinerja perusahaan dilihat dari EVA berkinerja tidak baik, Financial Value Added (FVA) menunjukkan kondisi perusahaan berkinerja baik dikarenakan nilai rata-rata FVA sebesar 40,318 diatas rata-rata industri -14,256 artinya kinerja perusahaan dilihat dari FVA berkinerja baik, Market Value Added (MVA) menunjukkan kondisi perusahaan berkinerja tidak baik dikarenakan nilai rata-rata MVA sebesar -29,527 diatas ratarata industri $-14,256$ artinya kinerja perusahaan dilihat dari MVA berkinerja tidak baik. 


\section{Analisis dan Interpretasi Economic Value Added (EVA) Pedekatan Time Series Approach}

Kinerja Keuangan Perusahan dari penilaian Analisis dan Interpretasi data secara Time Series Industri Konstruksi (BUMN) di Indonesia. Time Series Approach sebuah metode ini dapat mengetahui kondisi masing-masing variabel penelitian dari waktu ke waktu dalam priode tertentu.

Kinerja Keuangan Metode Economic Value Added (EVA) Industri Konstruksi (BUMN) di Indonesia dengan pendekatan data secara Time Series sebagai berikut: Tabel 5 : Rekapitulasi Economic Value Added (EVA) Industri Konstruksi (BUMN) di Indonesia Periode 2013-2017 (Dalam Milyaran Rupiah)

\begin{tabular}{|c|r|r|r|r|r|r|c|}
\hline $\begin{array}{c}\text { Nama Perusahaan } \\
\text { Konstruksi (BUMN) dI } \\
\text { Indonesia }\end{array}$ & \multicolumn{3}{|c|}{ Economic Value Added (EVA) } & \multirow{2}{*}{$\begin{array}{c}\text { Rata- } \\
\text { rata }\end{array}$} & Kinerja \\
\cline { 2 - 8 } & $\mathbf{2 0 1 3}$ & $\mathbf{2 0 1 4}$ & $\mathbf{2 0 1 5}$ & $\mathbf{2 0 1 6}$ & $\mathbf{2 0 1 7}$ & \\
\hline PT.Adhi Karya (Persero)Tbk & -16 & -96 & -312 & -219 & -100 & -149 & Baik \\
\hline PT. PP (Persero) Tbk & 24 & 54 & -33 & 298 & 196 & 108 & Baik \\
\hline PT.Wijaya Karya (Persero) & 287 & 136 & -124 & -496 & -888 & -217 & Baik \\
\hline PT. Waskita Karya (Persero) & 89 & 91 & 65 & -431 & $-5,248$ & $-1,087$ & Tidak Baik \\
\hline RATA-RATA INDUSTRI & 96 & 46 & -101 & -212 & $-1,510$ & $-\mathbf{3 3 6}$ & \\
\hline
\end{tabular}

Berdasarkan hasil perhitungan EVA pada Tabel 5, nilai rata-rata EVA perusahaan PT.Adhi Karya (Persero)Tbk, PT.Wijaya Karya (Persero) dan PT. Waskita Karya (Persero) pada tahun 2013-2017 adalah negatif ini berarti perusahaan tidak mampu memberikan nilai tambah bagi para pemegang sahamnya karena nilai EVA bernilai negatif (EVA < 0) sehingga dikatakan berkinerja tidak baik. sedangkan Nilai rata-rata EVA pada PT. PP (Persero) Tbk tahun 2013-2017 adalan positif ini berarti perusahaan mampu memberikan nilai tambah bagi para pemegang sahamnya karena nilai EVA bernilai positif $(E V A>0)$ sehingga dikatakan berkinerja baik.

Economic Value Added (EVA)) rata-rata industri Konstruksi (BUMN) di Indonesia periode 2013-2017 mengalami fluktuatif. Periode 2013 sd 2017 mengalami penurunan dari 96 tahun 2013 menjadi -1,510 pada tahun2017 ini berarti secara trend terjadi penurunan. Hal ini disebabkan adanya peningkatan biaya modal dan menunjukkan bahwa perusahaan dapat memberikan kembalian investasi sesuai dengan harapan investornya. dari tabel diatas terlihat rata-rata industry sebesar -336 , hal ini mengindikasikan bahwa perusahaan tidak mampu memberikan nilai tambah bagi para pemegang sahamnya karena nilai EVA bernilai negatif $(E V A<0)$ sehingga dikatakan berkinerja tidak baik.

6. Analisis dan Interpretasi Financial Value Added (FVA) dengan Pendekatan Time Series Approach Industri Konstruksi (BUMN) di Indonesia

Kinerja Keuangan Metode Financial Value Added (FVA) Industri Konstruksi (BUMN) di Indonesia dengan pendekatan data secara Time Series sebagai berikut : Tabel 6 : Rekapitulasi Financial Value Added (FVA) Industri Konstruksi (BUMN) di Indonesia Periode 2013-2017 (Dalam Milyaran Rupiah)

\begin{tabular}{|c|c|c|c|c|c|c|c|}
\hline \multirow{2}{*}{$\begin{array}{c}\text { Nama Perusahaan } \\
\text { Konstruksi (BUMN) dl } \\
\text { Indonesia }\end{array}$} & \multicolumn{5}{|c|}{ Financial Value Added (FVA) } & \multirow{2}{*}{$\begin{array}{l}\text { Rata- } \\
\text { rata }\end{array}$} & \multirow{2}{*}{ Kinerja } \\
\hline & 2013 & 2014 & 2015 & 2016 & 2017 & & \\
\hline PT.Adhi Karya (Persero)Tbk & -671 & -755 & $-1,078$ & $-1,082$ & -839 & -885 & $\begin{array}{l}\text { Tidak } \\
\text { Baik }\end{array}$ \\
\hline
\end{tabular}




\begin{tabular}{|c|r|r|r|r|r|r|c|}
\hline PT. PP (Persero) Tbk & 11,227 & 13,386 & 17,493 & 29,750 & 33,891 & 21,149 & Baik \\
\hline PT.Wijaya Karya (Persero) & 11,924 & 14,817 & 18,130 & 28,486 & 41,060 & 22,883 & Baik \\
\hline PT. Waskita Karya (Persero) & 8,141 & 11,625 & 28,929 & 57,856 & 95,042 & 40,318 & Baik \\
\hline RATA-RATA INDUSTRI & 7,656 & 9,768 & 15,869 & 28,752 & 42,288 & $\mathbf{2 0 , 8 6 7}$ & \\
\hline
\end{tabular}

Berdasarkan hasil perhitungan FVA pada Tabel 6, nilai rata-rata FVA perusahaan PT.Adhi Karya (Persero)Tbk, pada tahun 2013-2017 adalah negatif ini berarti perusahaan tidak mampu memberikan nilai tambah financial bagi perusahaan dan bagi para pemegang sahamnya sahamnya karena nilai FVA bernilai negatif (FVA < 0 ) sehingga dikatakan berkinerja tidak baik.. Sedangkan nilai rata-rata EVA pada PT. PP (Persero) Tbk, PT.Wijaya Karya (Persero), dan PT. Waskita Karya (Persero) tahun 2013-2017 adalan positif ini berarti perusahaan mampu memberikan nilai tambah financial bagi perusahaan dan bagi para pemegang sahamnya karena nilai FVA bernilai positif (EVA >0) sehingga dikatakan berkinerja baik.

Financial Value Added (FVA)) rata-rata industri Konstruksi (BUMN) di Indonesia periode 2013-2017 mengalami kenaikan Periode 2013 sd 2017 mengalami kenaikan dari 7,656 tahun 2013 menjadi 42,288 pada tahun 2017 ini berarti secara trend terjadi kenaikan. Hal ini disebabkan adanya pengurangan biaya modal dan menunjukkan bahwa perusahaan dapat memberikan keuntungan bagi investasi sehingga sesuai dengan harapan investornya. dari tabel diatas terlihat rata-rata industri sebesar 20,867, hal ini mengindikasikan bahwa perusahaan mampu memberikan nilai tambah financial bagi perusahaan dan bagi para pemegang sahamnya karena nilai FVA bernilai positif (FVA > 0) sehingga dikatakan berkinerja baik.

\section{Analisis dan Interpretasi Market Value Added (MVA) dengan Pendekatan Time} Series Approach Industri Konstruksi (BUMN) di Indonesia

Kinerja Keuangan Metode Market Value Added (MVA) Industri Konstruksi (BUMN) di Indonesia dengan pendekatan data secara Time Series sebagai berikut : Tabel 7 : Rekapitulasi Market Value Added (MVA) Industri Konstruksi (BUMN) di Indonesia Periode 2013-2017 (Dalam Milyaran Rupiah)

\begin{tabular}{|c|c|c|c|c|c|c|c|}
\hline $\begin{array}{c}\text { Nama Perusahaan } \\
\text { Konstruksi (BUMN) dl } \\
\text { Indonesia }\end{array}$ & \multicolumn{5}{|c|}{ Market Value Added (MVA) } & \multirow{2}{*}{$\begin{array}{c}\text { Rata- } \\
\text { rata }\end{array}$} & Kinerja \\
\cline { 2 - 8 } & $\mathbf{2 0 1 3}$ & $\mathbf{2 0 1 4}$ & $\mathbf{2 0 1 5}$ & $\mathbf{2 0 1 6}$ & $\mathbf{2 0 1 7}$ & \\
\hline PT.Adhi Karya (Persero)Tbk & $-3,179$ & $-3,418$ & $-7,347$ & $-7,051$ & $-10,700$ & $-6,339$ & Baik \\
\hline PT. PP (Persero) Tbk & $-3,602$ & $-4,773$ & $-8,388$ & $-15,354$ & $-18,502$ & $-10,124$ & Baik \\
\hline PT.Wijaya Karya (Persero) & $-2,890$ & $-7,179$ & $-8,988$ & $-16,435$ & $-19,688$ & $-11,036$ & Baik \\
\hline PT. Waskita Karya (Persero) & $-3,361$ & $-4,814$ & $-16,644$ & $-30,149$ & $-92,665$ & $-29,527$ & $\begin{array}{c}\text { Tidak } \\
\text { Baik }\end{array}$ \\
\hline RATA-RATA INDUSTRI & $-3,258$ & $-5,046$ & $-10,342$ & $-17,247$ & $-35,388$ & $-\mathbf{1 4 , 2 5 6}$ & $\begin{array}{c}\text { Tidak } \\
\text { Baik }\end{array}$ \\
\hline
\end{tabular}

Berdasarkan hasil perhitungan MVA pada Tabel 7, nilai rata-rata MVA perusahaan PT.Adhi Karya (Persero)Tbk, PT. PP (Persero) Tbk, PT.Wijaya Karya (Persero), dan PT. Waskita Karya (Persero) pada tahun 2013-2017 adalah negatif ini berarti perusahaan tidak mampu memberikan nilai tambah pasar dan bagi para pemegang sahamnya sahamnya karena nilai MVA bernilai negatif (MVA < 0) sehingga dikatakan berkinerja tidak baik. 
Market Value Added (MVA) rata-rata industri Konstruksi (BUMN) di Indonesia periode 2013-2017 mengalami fluktuatif. Periode 2013 sd 2017 mengalami penurunan dari -3,258 tahun 2013 menjadi -35,388 pada tahun 2017 ini berarti secara trend terjadi penurunan. Hal ini disebabkan adanya peningkatan biaya modal dan menunjukkan bahwa perusahaan dapat memberikan kembalian investasi sesuai dengan harapan investornya. dari tabel diatas terlihat rata-rata industry sebesar -14,256, hal ini mengindikasikan bahwa perusahaan tidak mampu memberikan nilai tambah financial bagi perusahaan dan bagi para pemegang sahamnya karena nilai MVA bernilai negatif (MVA < 0) sehingga dikatakan berkinerja tidak baik..

8. Penilaian Kinerja Keuangan Perusahaan pada Industri Konstruksi (BUMN) di Indonesia yang Listing Di Bursa Efek Indonesia Tahun 2013-2017 berdasarkan metode Economic Value Added (EVA), Financial Value Added (FVA) dan Market Value Added (MVA)

Hasil metode Analisis Economic Value Added (EVA), Financial Value Added (FVA) dan Market Value Added (MVA) pada Industri Konstruksi (BUMN) di Indonesia yang Listing di Bursa Efek Indonesia Tahun 2013-2017 sebagai berikut :

Tabel 8 : Analisis Economic Value Added (EVA), Financial Value Added (FVA) dan Market Value Added (MVA) Perusahaan pada Industri Konstruksi (BUMN) di Indonesia

\begin{tabular}{|c|c|c|c|c|c|c|c|}
\hline \multirow{2}{*}{ Variabel } & \multicolumn{4}{|c|}{ Kode Perusahaan } & \multirow{2}{*}{$\begin{array}{c}\text { Rata- } \\
\text { Rata } \\
\text { Industri }\end{array}$} & \multirow{2}{*}{ Sat } & \multirow{2}{*}{$\begin{array}{l}\text { Kinerja } \\
\text { Industri }\end{array}$} \\
\hline & ADHI & PTPP & WIKA & WSKT & & & \\
\hline Economic Value Added (EVA) & -149 & 108 & -217 & $-1,087$ & -336 & $\mathrm{Rp}$ & $\begin{array}{l}\text { Tidak } \\
\text { Baik }\end{array}$ \\
\hline Financial Value Added (FVA) & -885 & 21,149 & 22,883 & 40,318 & 20,867 & $\mathrm{Rp}$ & Baik \\
\hline Market Value Added (MVA) & $-6,339$ & $-10,124$ & $-11,036$ & $-29,527$ & $-14,256$ & $\mathrm{Rp}$ & $\begin{array}{c}\text { Tidak } \\
\text { Baik }\end{array}$ \\
\hline RATA-RATA & $-2,458$ & 3,711 & 3,877 & 3,235 & 2,091 & $\mathbf{R p}$ & Baik \\
\hline
\end{tabular}

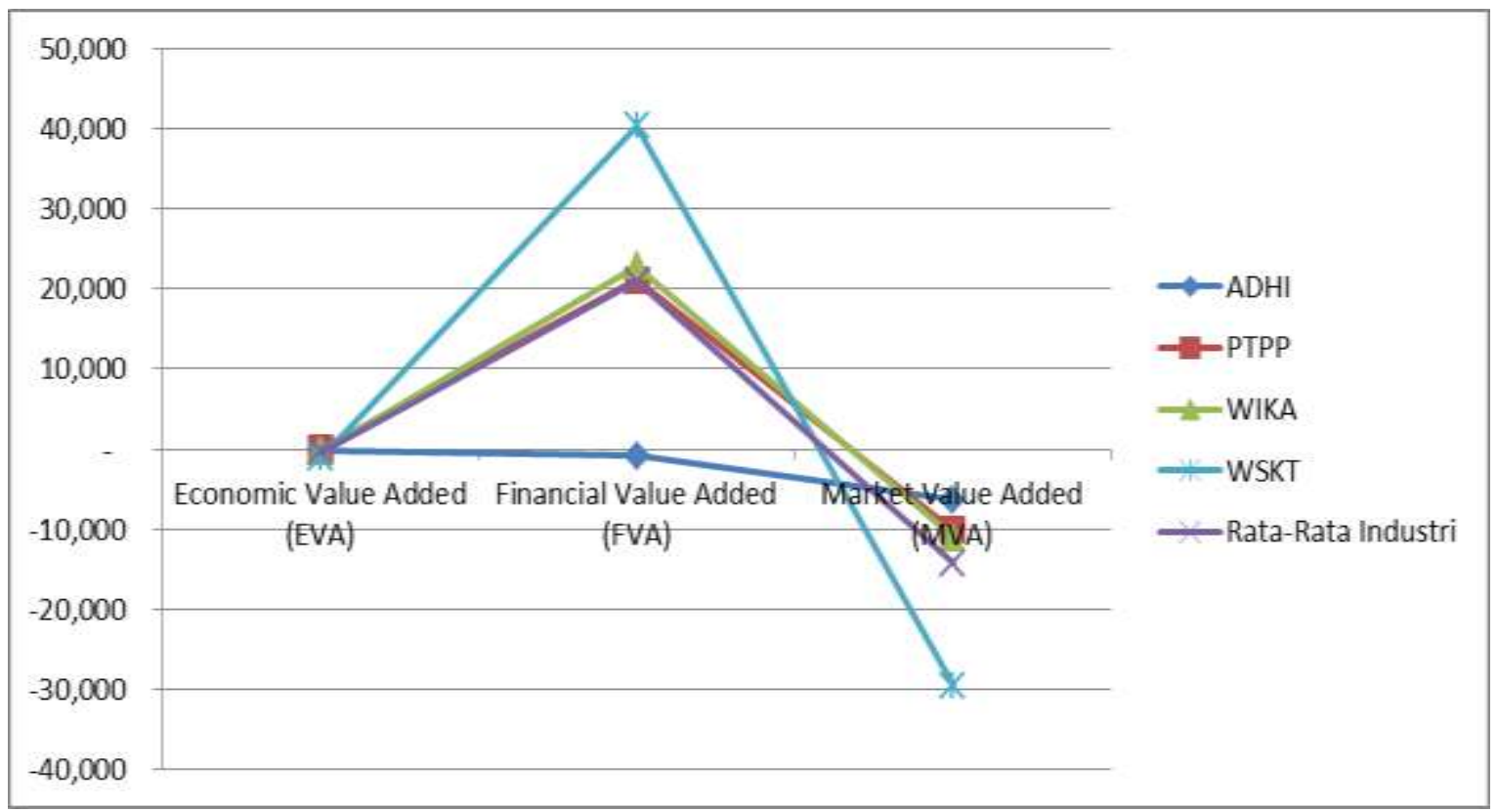


Setelah dilakukan perhitungan terhadap masing-masing variabel masing masing perusahaan dalam empat tahun berturut-turut sehingga dapat diketahui ratarata Analisis metode Analisis Economic Value Added (EVA), Financial Value Added (FVA) dan Market Value Added (MVA) pada Industri Perusahaan Konstruksi (BUMN) di Indonesia yang Listing di Bursa Efek Indonesia Tahun 2013-2017 sebesar 2,091 nunjukan hasill positif, Hal ini menunujukkan bahwa kondisi Industri Perusahaan Konstruksi (BUMN) di Indonesia secara keseluruhan dikatakan berkinerja BAIK.

\section{E. Kesimpulan dan Saran \\ 1. Kesimpulan}

Berdasarkan Analisis Economic Value Added (EVA), Financial Value Added (FVA) dan Market Value Added (MVA) dengan Time Series Approach (TSA) perusahaan Konstruksi (BUMN) di Indonesia yang Listing di Bursa Efek Indonesia Tahun 20132017 sebagai berikut :

a) Analisis Economic Value Added (EVA), untuk penilaian Kinerja Keuangan Industri Konstruksi (BUMN) di Indonesia yang Listing di Bursa Efek Indonesia Periode 2013-2017, nilai rata-rata EVA perusahaan PT.Adhi Karya (Persero)Tbk, PT.Wijaya Karya (Persero) dan PT. Waskita Karya (Persero) pada tahun 20132017 adalah negatif ini berarti perusahaan tidak mampu memberikan nilai tambah bagi para pemegang sahamnya karena nilai EVA bernilai negatif (EVA < 0) sehingga dikatakan berkinerja tidak baik. sedangkan Nilai rata-rata EVA pada PT. PP (Persero) Tbk tahun 2013-2017 adalan positif ini berarti perusahaan mampu memberikan nilai tambah bagi para pemegang sahamnya karena nilai EVA bernilai negatif (EVA $>0$ ) sehingga dikatakan berkinerja baik.

b) Analisis Financial Value Added (FVA) untuk penilaian Kinerja Keuangan Industri Konstruksi (BUMN) di Indonesia yang Listing di Bursa Efek Indonesia Periode 2013-2017, untuk penilaian Kinerja Keuangan Perusahaan PT.Adhi Karya (Persero)Tbk, pada tahun 2013-2017 adalah negatif ini berarti perusahaan tidak mampu memberikan nilai tambah financial bagi perusahaan dan bagi para pemegang sahamnya sahamnya karena nilai FVA bernilai negatif $(F V A<0)$ sehingga dikatakan berkinerja tidak baik.. Sedangkan nilai rata-rata EVA pada PT. PP (Persero) Tbk, PT.Wijaya Karya (Persero), dan PT. Waskita Karya (Persero) tahun 2013-2017 adalan positif ini berarti perusahaan mampu memberikan nilai tambah financial bagi perusahaan dan bagi para pemegang sahamnya karena nilai FVA bernilai positif (EVA > 0) sehingga dikatakan berkinerja baik.

c) Analisis Market Value Added (MVA) untuk penilaian Kinerja Keuangan Industri Konstruksi (BUMN) di Indonesia yang Listing di Bursa Efek Indonesia Periode 2013-2017, nilai rata-rata MVA perusahaan PT.Adhi Karya (Persero)Tbk, PT. PP (Persero) Tbk, PT.Wijaya Karya (Persero), dan PT. Waskita Karya (Persero) pada tahun 2013-2017 adalah negatif ini berarti perusahaan tidak mampu memberikan nilai tambah pasar dan bagi para pemegang sahamnya sahamnya karena nilai MVA bernilai negatif (MVA < 0 ) sehingga dikatakan berkinerja tidak baik.

d) Kinerja keuangan perusahaan Konstruksi (BUMN) di Indonesia yang Listing di Bursa Efek Indonesia Tahun 2013-2017, rata-rata Analisis metode Analisis Economic Value Added (EVA), Financial Value Added (FVA) dan Market Value Added (MVA) pada Industri Perusahaan Konstruksi (BUMN) di Indonesia yang Listing di Bursa Efek Indonesia Tahun 2013-2017 sebesar 2,091 nunjukan hasill positif, Hal ini menunujukkan bahwa kondisi Industri Perusahaan Konstruksi (BUMN) di Indonesia secara keseluruhan dikatakan berkinerja BAIK. 


\section{Saran}

Adapun saran yang dapat diberikan oleh peneliti atas penelitian yang telah dilakukan adalah sebagai berikut: Perusahaan dalam kategori ini harus lebih memfokuskan pada usaha perbaikan kinerja perusahaan untuk meningkatkan Economic Value Added (EVA), Financial Value Added (FVA) dan Market Value Added (MVA)tersebut..

\section{F. Daftar Pustaka}

.Anesti Iswandira 2015, Analisis economic value added (EVA) dan market value added (MVA) sebagai alat untuk mengukur kinerja keuangan perusahaan pt.indofood sukses makmur tbk., Jurnal Ilmiah Inovator, Edisi Maret 2015,

Anggoro Dwi Putra, 2014 Economic Value Added (EVA) dan Market Value Added (MVA) sebagai Alat Ukur Kinerja Keuangan (Studi Pada PT. HM Sampoerna, Tbk dan PT. Gudang Garam, Tbk Periode 2011-2013), Fakultas Ekonomi \& Bisnis, ABFI Institute Perbanas Jakarta

Atmaja, Lukas Setia. (2008) Teori dan Praktik Manajemen Keuangan. Yogyakarta: Penerbit Andi.

Atmaja, Lukas Setia. (2008). Teori dan Praktik Manajemen Keuangan. Yogyakarta:Penerbit Andi.

Brigham \& Houston. (2010) Dasar - Dasar Manajemen Keuangan (Essentials Of Financial Management). Edisi ke - 11. Salemba Empat. Jakarta. (Diterjemahkan oleh Ali Akbar Yulianto).

Darmawi, Herman. 2006, Pasar Finansial dan Lembaga-lembaga Finansial, PT Bumi Aksara, Jakarta.

Daulat Freddy dan Hildawati (2014), Analisis Kinerja Keuangan Perusahaan dengan Menggunakan Metode Du Pont System (Studi pada Perusahaan Food and Beverages yang terdaftar di BEI Periode Tahun 2008-2010), Forum Ilmiah, Volume 11 Nomor 2, Mei 2014, Universitas Esa Unggul, Jakarta.

Dendawijaya, Lukman, (2005). Manajemen Perbankan, Bogor Jakarta, Ghalia Indonesia.

Endang Fitriana (2016), Pengaruh NPF, CAR, dan EVA terhadap Profitabilitas Perusahaan Perbankan Syariah di BEI, Jurnal IImu dan Riset Manajemen : Volume 5, Nomor 4, April 2016, ISSN : 2461-0593, Sekolah Tinggi Ilmu Ekonomi Indonesia (STIESIA) Surabaya.

Erika Augusta, Nardi Sunardi, Leonardus Saiman,\& Abdul Kadim (2018) The Companies Performance With The Du Pont System Approach of Stocks Return and Its Implications on Company Value of Real Estate And Property Sector Listed In IDX, International Journal of Applied Business and Economic Research,. Volume 16, Number 1, 2018, ISSN : 0972-7302

Fraser, Lyn. M dan Ormiston, Aileen. (2008). Memahami Laporan Keuangan. Edisi ketujuh. Diterjemahkan oleh Priyo Darmawan. Jakarta:PT. Indeks

Gujarati, Damodar N .2003, Basic Econometrics, McGraw-Hill, $4^{\text {Th }}$ ed. New York

Husnan, S (2015). Teori Porto folio dan Analisis Investasi edisi Keempat. Yogyakarta: BPFE

Husnan, Suad dan Enny, Pudjiastuti (2006), "Dasar-dasar Manajemen Keuangan", Edisi Lima, Yogyakarta : UPP STIM YKPN

Husnan, Suad. Manajemen Keuangan (2008): Teori dan Penerapan Buku 1, Edisi 4, BPFE Yogyakarta

Ikatan Akuntan Indonesia. 2010. Pernyataan Standar Akuntansi Keuangan No. 19, Per 7 Maret 2016.

Iswati, Sri. (2007). Memprediksi Kinerja Keuangan Dengan Modal Intelektual Pada Perusahaan Perbankan Terbuka Di Bursa Efek Jakarta. Ekuitas .Vol 2, No 11: 159174 
Karim, Adiwarman. 2010. Bank Islam Analisis Fiqih dan Keuangan Edisi Keempat. Rajawali Press, Jakarta

Kasmir. 2012. Bank dan Lembaga Keuangan Lainnya. PT Raja Grafindo Persada

Kasmir. 2014. Analisis Laporan Keuangan. Jakarta:PT. Raja Grafindo Persada.

Katsir, Ibnu, 2003, Tafsir Ibnu Katsir, Jilid 1-7, Pustaka Imam Syafi'l, Bogor

Limpaphayom, Piman, dan Siraphat Polwitoon, (2004), "Bank Relationship and Firm Performance: Evidence from Thailand before The Asian Financial Crisis," Journal of Bussiness Finance and Accounting, 2004

M. Ridho Firdausi, Dadan R.,\& AS. Dewi 2017 Analisis kinerja keuangan dengan menggunakan metode economic value added (EVA), financial value added (FVA) dan market value added (MVA), e-Proceeding of Management : Vol.4, No.2 Agustus 2017 | Page 1413.

Machmud, Amir dan Rukmana. 2010. Bank Syariah Teori, Kebijakan, dan Studi Empiris di Indonesia. Jakarta: Erlangga.

Mamduh, M. Hanafi (2003) Analisis Laporan Keuangan. Edisi Revisi, Cetakan Pertama, Yogyakarta: UPP AMP YKPN.

Mamik Mardiani 2012. Penilaian Kinerja Keuangan Perusahaan Menggunakan Analisis Rasio Keuangan dan Konsep Eva (Economic Value Added) Studi Pada PT HM Sampoerna, Tbk. yang Terdaftar di BEI Periode Tahun 2009-2011, Fakultas IImu Administrasi, Universitas Brawijaya

Millward Brown, 2015, 2015 BrandZ Top 100 Global Brands, Per December 2015,http://www.millwardbrown.com/brandz/top-globalbrands/2015/introduction

Muharam, Harjum dan Pusvitasari. 2007. Analisis Perbandingan Efisiensi Bank Syariah di Indonesia dengan Metode Data Envelopment Analysis. Jurnal Ekonomi dan Bisnis Islam. Vol.2 No.3 Hal: 80-116

Munawir, S. (2007) Analisa Laporan Keuangan. Edisi Keempat, Cetakan Keempat belas, Yogyakarta: Liberty.

Mursalim, 2009 Economic Value Added dan Market Value Added Dampaknya Terhadap Nilai Perusahaan, Jurnal Keuangan dan Perbankan, Vol. 13, No.3 September 2009, hal. $498-505$

Nachrowi, Djalal Nachrowi, Hardius Usman. 2006. Pendekatan Populer dan Praktis Ekonometruka untuk Analisis Ekonomi dan Keuangan, Lembaga Penerbit Universitas Indonesia, Jakarta

Nardi Sunardi (2017) Determinan Kebijakan Utang Serta Implikasinya terhadap Kinerja Perusahaan (Perusahaan yang tergabung dalam indeks LQ.45 yang terdaftar di Bursa Efek Indonesia Tahun 2011- 2015) Jurnal Sekuritas, Vol. 1, No.1 I September 2017 Universitas Pamulang.

Nardi Sunardi 2018, Analisis Du Pont System Dengan Time Series Approach (Tsa) Dan Cross Sectional Approach (Csa) Dalam Penilaian Kinerja Keuangan Perusahaan (Studi Pada Industri Konstruksi (BUMN) di Indonesia Yang Listing di BEI Tahun 2013-2017), Jurnal Sekuritas (Saham, Ekonomi, Keuangan dan Investasi) Vol.1, No.4, Juni 2018, Halaman : 1-15, Unversitas Pamulang.

Nardi Sunardi, Aceng Abdul Hamid, Lativa, Abdul Kadim, Natanael Tulus (2018) Determinant Of Cost Efficiency And It's Implications For Companies Performance Incorporated In The Lq.45 Index Listing In Idx For The Period of 2011-2016, International Journal of Applied Business and Economic Research,.Volume 16, Number 1, 2018, ISSN : 0972-7302

Nataly, Daisy, 2011, “Knowledge Management”, Makalah pada MB IPB, Bogor 18 Maret 2011.

Nuraini,Topowijono dan F.Yaningwati (2015), Penilaian Kinerja Keuangan Perusahaan Menggunakan Analisis Return On Investment (ROI) Dengan Pendekatan Du Pont System Dan Residual Income (RI) (Studi Pada Perusahaan Kosmetik Dan 
Keperluan Rumah Tangga Yang Listing Di Bursa Efek Indonesia Tahun 2011-2013), Jurnal Administrasi Bisnis (JAB)|Vol. 26 No. 2 September 2015.

Organization for Economic Co-operation and Development (OECD). 1999. International Symposium on Measuring and Reporting Intellectual Capital, Experience, Issues and Prospects. Amsterdam, 9-11 June 1999.

Otoritas Jasa Keuangan, 2015, Roadmap Perbankan Syariah Indonesia 2015-2019, Departemen Perbankan Syariah OJK, Jakarta

Pangestika, Styfanda, 2015, Analisis Estimasi Moel Regresi Data Panel Dengan Pendekatan Common Effect Model (CEM), Fixed Effect Model (FEM), dan Random Effect Model (REM), Skripsi Fakultas MIPA Universitas Negeri Semarang, tidak dipublikasikan

Peraturan Perundang-undangan, 1992, Undang-undang Republik Indonesia Tahun 1992 Tentang Perbankan, DPR-RI, Jakarta

Riyadi Slamet, 2006. Banking Assets and Liability Management (Edisi Ketiga). Jakarta: Lembaga Penerbit Fakultas Ekonomi Universitas Indonesia, 2006.

Rose, Peter S and Sylvia C Hudgins (2010) Bank Management and Financial Services. New York : Mc Grow Hill

Salman, R. T., Mansor, M., Babatunde, A. D., Tayib, M. 2012, Impact of Intellectual Capital on Return on Asset in Nigerian Manufacturing Companies, Interdisciplinary Journal of Research in Business, Vol. 2 No. 4, hal. 21-30.

Sufian, Fadzlan and Royfaizal Razali Chong. 2008. Determinants of Bank Profitability in A Developing Economy: Empirical Evidence From The Philippines. Asian Academy of Management Journal of Accounting and Finance, 4(2): 91112.

Taswan. 2010. Manajemen Perbankan, Konsep, Teknik, dan Aplikasi. Edisi Kedua. Yogyakarta : UPP STIM YKPN.

Usman, Bahtiar. 2003. Analisis Rasio Keuangan dalam Memprediksi Perubahan Laba pada Bank-Bank di Indonesia. Media Riset \& Manajemen. Vol.3 (1)

Vandi Surya Winata 2016, Penggunaan Analisis Kinerja Keuangan Perusahaan Dengan Pendekatan Economic Value Added (Eva) Dan Market Value Added (Mva) Pada Perusahaan Manufaktur Yang Go Public Di Bursa Efek Indonesia Tahun 2012-2015, e-Journal S1 Ak Universitas Pendidikan Ganesha, Jurusan Akuntansi Program S1 (Vol: 6 No: 3 Tahun 2016)

Viandina Puspita, 2015 pengaruh economic value added (EVA) dan market value added (MVA) terhadap harga saham pada perusahaan kelompok lq-45 di bursa efek indonesia, Jembatan - Jurnal IImiah Manajemen Bisnis Dan Terapan Tahun XII No 2, Oktober 2015

White, D. Steven, Gunasekaran, Angappa. Ariguzo, Godwin C. 2013, "The Structural Components of a Knowledge-based Economy", Int. J. Business Innovation and Research, Vol. 7, No. 4, hal. 504-518

Winarni, F dan Sugiyarso, G. (2005). Manajemen Keuangan. Yogyakarta: Liberty.

Zuhal. 2010. Knowledge \& Inovation sebagai Platform Kekuatan Daya Saing. PT. Gramedia Pustaka Utama, Jakarta 